\title{
HUBUNGAN KARAKTERISTIK PASIEN TERHADAP TINGKAT KEPERCAYAAN ATAS PELAYANAN YANG DIBERIKAN OLEH DOKTER RESIDEN DI RUANG RAWAT INAP RUMAH SAKIT UMUM PUSAT SANGLAH DENPASAR TAHUN 2017
}

\author{
Ni Made Mas Dwi Purwaningrat*, Pande Putu Januraga, Putu Ayu Indrayathi \\ Program Studi Kesehatan Masyarakat Fakultas Kedokteran Universitas Udayana \\ *Email:dekmasdwi15@gmail.com
}

\begin{abstract}
ABSTRAK
Salah satu faktor yang paling mempengaruhi kepercayaan pasien adalah kualitas pelayanan yang diberikan, dimana pentingnya karakteristik pasien sebagai penentu utama pembentukan persepsi terhadap suatu pelayanan di rumah sakit. Tujuan penelitian ini adalah untuk mengetahui hubungan karakteristik pasien terhadap tingkat kepercayaan pasien atas pelayanan yang diberikan oleh dokter residen. Penelitian ini dilakukan di Ruang Rawat Inap Kelas III RSUP Sanglah Denpasar. Desain penelitian menggunakan rancangan Cross Sectional analitik kuantitatif. Sampel diambil dengan teknik consecutive sampling sebanyak 109 responden. Analisis data dilakukan dengan uji statistik Chi Square Fisher Exact's untuk melihat hubungan karakteristik pasien terhadap tingkat kepercayaan atas pelayanan yang diberikan oleh dokter residen. Hasil penelitian menunjukkan bahwa ada hubungan antara karakteristik pendidikan pasien $(p=0,014)$ dan karakteristik umur $(\mathrm{p}=0,043)$ dengan tingkat kepercayaan pasien atas pelayanan dokter residen. Tetapi tidak ada hubungan antara jenis kelamin $(\mathrm{p}=0,104)$ dan pekerjaan $(\mathrm{p}=0,751)$ dengan tingkat kepercayaan pasien atas pelayanan dokter residen. Karakteristik umur responden rata-rata 42,02 pada kelompok umur $\leq 45$ tahun, jenis kelamin perempuan, pasien lebih banyak berpendidikan SMA/SMK dan berstatus bekerja. Pasien memiliki tingkat kepercayaan yang tinggi atas pelayanan dokter residen (82,57\%). Ada hubungan antara karakteristik pendidikan dan karakteristik umur dengan tingkat kepercayaan pasien atas pelayanan dokter residen. Untuk mencapai target kepercayaan pelanggan, dapat dilakukan dengan menjelaskan pelayanan yang diberikan oleh dokter residen kepada pasien yang memiliki umur lanjut usia serta berpendidikan rendah.
\end{abstract}

Kata Kunci : Kepercayaan Pasien, Rumah Sakit, Karakteristik

\begin{abstract}
Patient's Trust is one factors that influences the quality of services provided by hospital. In order to determine the level of patient trust, hospital needs to comprehend the characteristic of patients for decision making related to services provides by the hospital. The purpose of this study was to find out the relationship of patient characteristic towards level of trust for the service provided by resident doctors. This research was conducted in class III inpatient room at Sanglah Hospital Denpasar. This study is a cross sectional with quantitative approach. Samples were taken by consecutive sampling technique with 109 respondents. Data analysis was performed with Chi Square Exact's Statistical Test to find out the relationship of patient characteristics toward level of trust in the services provided by resident doctors. Patient characteristic in this study include age, sex, education, and occupation. Study found that 90 respondents $(82,57 \%)$ had high level of trust in the services provided by resident doctors .There was a relationship between the characteristics of patient education ( $\mathrm{p}=0.014)$ and age characteristics $(p=0.043)$ with the level of patient trust in the services of resident doctors. But there is no relationship between sex and occupation with $p$ value 0.104 and 0.751 respectively. Therefore, to achieve target of customer trust, it can be done by explaining the services provided by resident doctors to elderly patients and low education.
\end{abstract}

Keywords : patient trust, hospital, characteristics

\section{PENDAHULUAN}

Rumah sakit adalah istitusi pelayanan kesehatan yang menyelenggarakan pelayanan kesehatan perorangan secara paripurna yang menyediakan pelayanan rawat inap, rawat jalan, dan gawat darurat. 
Sebagai salah satu institusi pelayanan kesehatan, Rumah Sakit Umum Pusat (RSUP) Sanglah Denpasar yang merupakan rumah sakit pendidikan utama, dimana memiliki fungsi sebagai tempat pendidikan, penelitian, dan pelayanan kesehatan serta sebagai rumah sakit yang cukup sibuk baik dalam pelayanan kesehatan yang diberikan dan sebagai sarana pendidikan akan berisiko terhadap keamanan serta keselamatan pasien.

RSUP Sanglah Denpasar dalam penerapan indikator mutu pelayanan kesehatan menjadi hal yang sangat penting bagi keberlangsungan pelayanan kesehatan yang diberikan, dimana berdasarkan evaluasi program peningkatan mutu dan keselamatan pasien proporsi insiden keselamatan pasien pada bulan JuliSeptember 2016 yakni kejadian tidak cidera (KTC) sebesar 12,9\%, kondisi potensial cidera (KPC) sebesar 19,7\%, Kejadian Tidak Diinginkan (KTD) sebesar 31,7\% dan Kejadian Nyaris Cedera (KNC) sebesar $33,8 \%$ serta indikator mutu pelayanan yang kurang mencapai target indikator kepuasan pelanggan terhadap pelayanan peserta didik di tahun 2016 yang ditargetkan mencapai $80 \%$, namun hanya mencapai $76 \%$ (RSUP Sanglah Denpasar, 2016). Terjadinya penurunan target capaian indikator kepuasan pelanggan sebesar 10\% menunjukan semakin menurunnya rasa kepuasan pelanggan terhadap layanan peserta didik.

Berdasrkan 5 dimensi mutu pelayanan kesehatan, dimana kepercayaan merupakan salah satu bagian dari indikator mutu yakni pada dimensi assurance (jaminan), dalam dimensi tersebut yakni terdapat kredibilitas (credibility) yang mencakup kepercayaan terhadap kejujuran dari pemberi layanan. Sehingga keterkaitan antara 5 dimensi mutu pelayanan dan kualitas pelayanan yang diberikan akan berdampak pada tingkat kepercayaan pasien pada dokter yang memberikan pelayanan kesehatan. Untuk melihat tingkat kepercayaan pasien tersebut, menurut Hidayati (2013) pihak rumah sakit perlu memahami karakteristik pasien untuk pengambilan keputusan terkait dengan pelayanan yang diberikan rumah sakit.

Berdasarkan latar belakang tersebut, penulis tertarik untuk melakukan penelitian mengenai hubungan karakteristik pasien terhadap tingkat kepercayaan atas pelayanan yang diberikan oleh dokter residen di ruang rawat inap Rumah Sakit Umum Pusat Sanglah Denpasar tahun 2017.

\section{METODE}

Penelitian menggunakan metode observasional analitik dengan desain penelitian cross sectional. Populasi penelitian adalah seluruh pasien yang dinyatakan menjalani rawat inap kelas III yang $>3$ hari di RSUP Sanglah Denpasar. Sampel yang digunakan sebanyak 109 responden dengan kriteria inklusi pasien yang mengetahui kriteria dokter residen. Teknik pengambilan sampel dilakukan dengan cara consecutive sampling. Instrumen penelitian yang digunakan berupa kuesioner penelitian.

\section{HASIL}

\section{a. Jumlah Pasien yang Mengetahui status Dokter Residen}

Dalam penelitian ini sebelum pasien dinyatakan sebagai responden penelitian, terlebih dahulu dilaksanakan seleksi responden yang memahami status dokter 
yang memberikan pelayanan kesehatan adalah dokter residen, tersebut mendapatkan hasil sesuai dengan tabel diatas yakni sebanyak 69 pasien (51,49\%) pasien mengetahui status dokter residen yang memberikan pelayanan kesehatan, 40 pasien $(29,85 \%)$ pasien mengetahui status dokter residen setelah mendapatkan penjelasan terkait dengan kriteria dokter residen dan sebanyak 25 pasien (18,66\%) pasien tidak mengetahui status dokter residen walaupun telah diberikan penjelasan terkait dengan kriteria dokter residen. Jadi berdasarkan screening kuesioner tersebut, pasien yang dapat dijadikan responden penelitian sebanyak 109 responden.

Tabel 1. Distribusi Frekuensi Pasien yang Mengetahui Status Dokter Residen

\begin{tabular}{llcc}
\hline No. & $\begin{array}{l}\text { Status Dokter } \\
\text { Residen }\end{array}$ & F & \% \\
\hline 1. & $\begin{array}{l}\text { Mengetahui } \\
\text { Status Dokter } \\
\text { Residen } \\
\text { 2. }\end{array}$ & 69 & 51,49 \\
& $\begin{array}{l}\text { Mengetahui } \\
\text { Satatus Dokter } \\
\text { Residen } \\
\text { Setelah }\end{array}$ & 40 & 29,85 \\
& & \\
Dijelaskan & & \\
& Tidak \\
& Mengetahui \\
& Status Dokter \\
& Residen & \\
\multicolumn{1}{c}{ Total } & $\mathbf{1 3 4}$ & $\mathbf{1 0 0}$ \\
\hline
\end{tabular}

b. Karakteristik Pasien

Karakteristik pasien dalam penelitian ini meliputi umur, jenis kelamin, pendidikan dan pekerjaan yang disajikan pada tabel 2 . Berdasarkan tabel 2 dapat dilihat bahwa distribusi karakteristik umur pasien cenderung lebih banyak berumur 21-40 tahun sebanyak 53 pasien $(48,62 \%)$ dengan rata-rata 42,02. Pasien lebih banyak berjenis kelamin perempuan yakni sebanyak 62 pasien (56,88\%). Pasien lebih banyak berpendidikan tinggi sebanyak 54 pasien (49,54\%) dan pasien lebih banyak berstatus bekerja yakni sebanyak 89 pasien $(81,65 \%)$.

\section{Tabel 2. Karakteristik Pasien}

\begin{tabular}{llccc}
\hline No. & Karakteristik & F & \% & $\begin{array}{c}\text { Mean } \\
\text { (SD) }\end{array}$ \\
\hline 1. & Umur & & & \\
& a.21-40 Tahun & 53 & 48,62 & 42,02 \\
& b. $41-60$ Tahun & 48 & 44,04 & $(13,68$ \\
& c. $>60$ Tahun & 8 & 7,34 &
\end{tabular}

2. Jenis

Kelamin
a. Laki - laki
$47 \quad 43,12$
b. Perempuan $62 \quad 56,88$

3. Pendidikan

\begin{tabular}{llll}
\multicolumn{2}{l}{ a.Pendidikan } & \\
\multicolumn{2}{l}{ rendah } & 10 & 9,17 \\
b. SD & 26 & 23,85 \\
c. SMP & 19 & 17,43 \\
d. Sendi & 54 & 49,54
\end{tabular}

\section{Pekerjaan}

\begin{tabular}{|c|c|}
\hline a. Bekerja & 89 \\
\hline $\begin{array}{ll}\text { b. } & \text { Tidak } \\
\text { Bekerja } & \end{array}$ & 20 \\
\hline
\end{tabular}

c. Tingkat Kepercayaan Pasien atas

Pelayanan yang diberikan oleh Dokter Residen

Tingkat kepercayaan pasien atas pelayanan yang diberikan oleh dokter residen dikategorikan menjadi 3 kategori yakni kepercayaan tinggi, sedang dan kurang atas pelayanan kesehatan yang diberikan oleh dokter residen. Berdasarkan tabel 3 dapat dilihat bahwa tabulasi data tingkat kepercayaan pasien atas pelayanan yang diberikan oleh dokter residen menunjukan 90 
responden $(82,57 \%)$ lebih banyak memiliki tingkat kepercayaan tinnggi atas pelayanan yang diberikan oleh dokter residen, 19 responden $(17,43 \%)$ memiliki tingkat kepercayaan rendah serta tidak ada responden yang memiliki kepercayaan kurang atas pelayanan yang diberikan oleh dokter residen.

Tabel 3. Distribusi Frekuensi Tingkat Kepercayaan Pasien atas Pelayanan yang diberikan oleh Dokter Residen

\begin{tabular}{|c|c|c|c|}
\hline No. & Kategori & $\mathbf{F}$ & $\%$ \\
\hline 1. & Sedang & 19 & 17,43 \\
\hline \multirow[t]{2}{*}{2.} & Tinggi & 90 & 82,57 \\
\hline & Total & 62 & 100 \\
\hline
\end{tabular}

d. Hubungan Karakteristik Pasien dengan Tingkat Kepercayaan Pasien atas Pelayanan yang diberikan oleh Dokter Residen

Berdasarkan tabel 4 diatas dapat dilihat bahwa proporsi karakteristik umur responden dengan tingkat kepercayaan sedang atas pelayanan yang diberikan oleh dokter residen, lebih cenderung pada kelompok umur 40-60 tahun sebesar 20,83\%, sedangkan tingkat kepercayaan tinggi atas pelayanan yang diberikan oleh dokter residen lebih cenderung pada kelompok umur 21-40 tahun sebesar 90,57\%.

Berdasarkan hasil uji analisis hubungan dengan uji Chi-Square Fisher's Excact antara karakteristik umur pasien dengan tingkat kepercayaan pasien atas pelayanan yang diberikan oleh dokter residen diperoleh nilai $\mathrm{p}$ value $=0,043 \quad(\mathrm{p} \leq 0,05)$ yang menyatakan ada hubungan yang bermakna antara karakteristik umur pasien dengan tingkat kepercayaan pasien atas pelayanan yang diberikan oleh dokter residen di RSUP Sanglah Denpasar.

Proporsi karakteristik berdasarkan jenis kelamin responden dimana jenis kelamin perempuan dan laki-laki lebih cenderung memiliki tingkat kepercayaan tinggi atas pelayanan yang diberikan oleh dokter residen, dimana jumlah responden perempuan sebanyak 48 responden $(77,42 \%)$ serta jumlah responden laki-laki sebanyak 42 responden $(89,36 \%)$.

Berdasarkan hasil uji analisis hubungan dengan uji Chi-Square Fisher's Exact antara karakteristik jenis kelamin pasien dengan tingkat kepercayaan pasien atas pelayanan yang diberikan oleh dokter residen diperoleh nilai $p$ value $=0,104(p>0,05)$ yang menyatakan bahwa tidak ada hubungan yang bermakna antara karakteristik jenis kelamin pasien dengan tingkat kepercayaan pasien atas pelayanan yang diberikan oleh dokter residen di RSUP Sanglah Denpasar.

Proporsi karakteristik berdasarkan pendidikan pasien yang cenderung memiliki tingkat kepercayaan sedang atas pelayanan yang diberikan oleh dokter residen sebesar $23,08 \%$ berpendidikan $S D$, sedangkan responden yang cenderung memiliki tingkat kepercayaan tinggi pada pelayanan dokter residen berpendidikan tinggi sebesar $90,74 \%$.

Berdasarkan hasil uji analisis hubungan dengan uji Chi-Square Fisher's Exact antara karakteristik pendidikan pasien dengan tingkat kepercayaan pasien atas pelayanan yang diberikan oleh dokter residen diperoleh nilai $p$ value $=0,014(p \leq 0,05)$ yang menyatakan bahwa ada hubungan yang bermakna antara karakteristik pendidikan pasien dengan tingkat kepercayaan pasien 
atas pelayanan yang diberikan oleh dokter residen di RSUP Sanglah Denpasar.

Proporsi karakteristik berdasarkan pekerjaan pasien yang bekerja dan tidak bekerja sama-sama memiliki tingkat kepercayaan tinggi atas pelayanan yang diberikan oleh dokter residen, dimana responden yang tidak bekerja dengan tinggkat kepercayaan tinggi sebanyak 17 responden $(85 \%)$ serta responden yang bekerja dengan tingkat kepercayaan tinggi atas pelayanan dokter residen sebanyak 73 responden $(82,02 \%)$.

Berdasarkan hasil uji analisis hubungan dengan uji Chi-Square Fisher's Exact antara karakteristik pekerjaan pasien dengan tingkat kepercayaan pasien atas pelayanan yang diberikan oleh dokter residen diperoleh nilai $p$ value $=0,751(p>0,05)$ yang menyatakan tidak ada hubungan yang bermakna antara karakteristik pekerjaan pasien dengan tingkat kepercayaan pasien atas pelayanan yang diberikan oleh dokter residen di RSUP Sanglah Denpasar.

\section{DISKUSI}

Berdasarkan distribusi frekuensi tingkat kepercayaan pasien atas pelayanan yang diberikan oleh dokter residen didapatkan responden cenderung memiliki tingkat kepercayaan tinggi terhadap pelayanan yang diberikan oleh dokter residen.

Tabel 4. Distribusi Frekuensi Hubungan Karakteristik Pasien dengan Tingkat

Kepercayaan Pasien atas Pelayanan yang diberikan oleh Dokter Residen

\begin{tabular}{|c|c|c|c|c|c|c|c|}
\hline \multirow{3}{*}{$\begin{array}{c}\text { Karakteristik } \\
\text { Pasien }\end{array}$} & \multicolumn{4}{|c|}{$\begin{array}{c}\text { Kepatuhan Berobat Penderita } \\
\text { Tuberkulosis }\end{array}$} & & & \multirow{3}{*}{$\mathbf{P}$} \\
\hline & \multicolumn{2}{|c|}{ Sedang } & \multicolumn{2}{|c|}{ Tinggi } & \multicolumn{2}{|c|}{ Total } & \\
\hline & $\mathbf{F}$ & $\%$ & $\mathbf{F}$ & $\%$ & $\mathbf{F}$ & $\%$ & \\
\hline \multicolumn{8}{|l|}{ Umur } \\
\hline a.21-40 Tahun & 5 & 9,43 & 48 & 90,57 & 53 & 100 & \\
\hline b. 40-60 Tahun & 10 & 20,83 & 38 & 79,17 & 48 & 100 & 0,043 \\
\hline c. $>60$ Tahun & 4 & 50,00 & 4 & 50,00 & 8 & 100 & \\
\hline \multicolumn{8}{|l|}{ Jenis Kelamin } \\
\hline a. Perempuan & 14 & 22,58 & 48 & 77,42 & 62 & 100 & 0,104 \\
\hline b. Laki - laki & 5 & 10,64 & 42 & 89,36 & 47 & 100 & \\
\hline \multicolumn{8}{|l|}{ Pendidikan } \\
\hline $\begin{array}{l}\text { a. Pendidikan } \\
\text { Rendah }\end{array}$ & 5 & 50,00 & 5 & 50,00 & 10 & 100 & \\
\hline b. SD & 6 & 23,08 & 20 & 76,92 & 26 & 100 & 0,014 \\
\hline c. SMP & 3 & 15,79 & 16 & 84,21 & 19 & 100 & \\
\hline $\begin{array}{l}\text { d. Pendidikan } \\
\text { Tinggi }\end{array}$ & 5 & 9,62 & 49 & 90,74 & 54 & 100 & \\
\hline \multicolumn{8}{|l|}{ Pekerjaan } \\
\hline $\begin{array}{l}\text { a. Tidak } \\
\text { Bekerja }\end{array}$ & 3 & 15,00 & 17 & 85,00 & 20 & 100 & 0,751 \\
\hline b. Bekerja & 16 & 17,98 & 73 & 82,02 & 89 & 100 & \\
\hline
\end{tabular}


Dengan melihat hasil tersebut dapat dilihat bahwa pasien yang diberikan pelayanan oleh dokter residen selama menjalani rawat inap memiliki tingkat kepercayaan tinggi atas pelayanan yang diberikan. Hal ini sesuai dengan tercapainya indikator yang membentuk kepercayaan pasien menurut Joseph, et al (2010) dalam Erviana (2013) yakni kemampuan pemberi layanan menyediakan, melayani sampai pada keselamatan dan keamanan pasien,

kebaikan hati sebagai kemampuan pemberi layanan dalam memberikan manfaat yang saling menguntungkan dengan pasien serta integritas dalam menjalankan pelayanan kesehatan baik dari informasi yang diberikan sampai dengan kualitas pelayanan yang diterima pasien. Selain itu sejalan dengan tingginya tingkat kepercayaan pasien atas pelayanan yang diberika oleh dokter residen hal ini sejalan dengan penelitian yang dilakukan oleh Kartikasari (2014) yang menyatakan bahwa meningkatnya kualitas layanan akan meningkatkan kepercayaan pasien dan menurunnya kualitas layanan akan menurunkan kepercayaan pasien.

Berdasarkan hasil analisis bivariat karakteristik pasien dengan tingkat kepercayaan pasien atas pelayanan yang diberikan oleh dokter residen diperoleh hasil dimana karakteristik pendidikan dan karakteristik umur memiliki hasil yang bermakna diantara 4 karakteristik lainya dengan $\mathrm{p}$ value karakteristik pendidikan

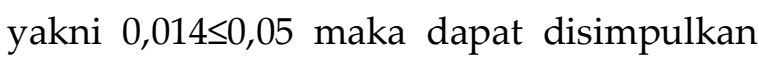
ada hubungan yang bermakna antara karakteristik pendidikan pasien dengan tingkat kepercayaan pasien atas pelayanan yang diberikan oleh dokter residen. Hasil penelitian ini sejalan dengan penelitian Yuniarta (2011) dengan nilai $\mathrm{p}$ value $=0,000$ $<0,05$ yang menunjukan bahwa terdapatnya hubungan yang bermakna antara tingkat pendidikan pasien terhadap kepuasan pemberian informed consent. Hal ini dikarenakan semakin tingginya pendidikan pasien maka semakin tinggi pula keinginan, harapan dan kepercayaan dari pasien atau keluarga pasien terhadap segala penanganan medis yang dilakukan oleh tim medis demi keselamatan dan kesembuhan pasien.

Hasil penelitian ini tidak sejalan dengan hasil penelitian Kurniasih (2010) yang menunjukan faktor pendidikan tidak memiliki hubungan yang bermakna dengan tingkat kepercayaan pasien dalam tindakan medis di Semarang Eye Center (SEC) Rumah Sakit Islam Sultan Agung Semarang dengan nilai $\mathrm{p}$ value $=0,389$. Namun, dilihat berdasrkan kualitas pelayanan kesehatan yang akan berdampak pada meningkatnya tingkat kepercayaan pasien, dimana tingkat pendidikan memiliki hubungan yang bermakna terhadap kualitas pelayanan kesehatan yakni sejalan dengan penelitian Prasetiyo (2015) yang telah menunjukan $p$ value $=0,031<0,05$. Ini sesuai dengan pendapat Ruditya \& Chalidyanto (2015) yang menyatakan bahwa tingkat pendidikan seseorang yang lebih tinggi akan cenderung memiliki perilaku hidup yang lebih sehat serta keyakinan terhadap suatu pelayanan kesehatan yang diberikan oleh dokter akan berbeda dibandingkan dengan yang tidak. Sehingga dampaknya terhadap kepercayaan yakni semakin 
tingginya tingkat pendidikan responden maka semakin tinggi pula tingkat kepercayaannya terhadap pemberi layanan kesehatan.

Berdasarkan hasil analisis bivariat karakteristik umur pasien dengan tingkat kepercayaan pasien atas pelayanan yang diberikan oleh dokter residen diperoleh $\mathrm{p}$ value umur 0,043 $\leq 0,05$, maka dapat disimpulkan ada hubungan yang bermakna antara umur pasien dengan tingkat kepercayaan pasien atas pelayanan yang diberikan oleh dokter residen. Hubungan antara umur dengan tingkat kepercayaan pasien secara statistik dalam penelitian ini tidak bermakna disebabkan oleh sifat homogenitas data penelitian dimana jumlah responden yang dominan adalah kelompok umur $<42$ tahun dimana rentangan umur tersebut juga cenderung menghasilkan tingkat kepercayaan tinggi daripada kepercayaan sedang dan rendah. Ini disebabkan dilihat berdasasrkan umur yang $<42$ tahun telah memiliki kapasitas intelektual yang baik sehingga cenderung aktif untuk menambah pengetahuan yang mereka miliki dan sebagai pembentuk persepsi pasien. Sebagai pembentuk persepsi pasien, karakteristik umur dan pendidikan menjadi patokan seseorang untuk dapat membuat suatu keyakinan/kepercayaan terhadap suatu pelayanan kesehatan yang diberikan. Dengan tercapainya suatu kepercayaan pasien atas pelayanan yang diberikan menurut pendapat Respati (2013) dimana kepercayaan merupakan salah satu indikator mutu pelayanan yang terdapat dalam 5 dimensi mutu serta didukung pendapat Sari (2013) dapat menjadi suatu pertimbangan pasien dalam memilih suatu pelayanan kesehatan dengan prioritas ukuran kualitas pelayanan yang akan cenderung menjadi sumber utama terbentuknya tingkat kepuasan pasien yang akan mengarah pada peningkatan tingkat kepercayaan pasien atas pelayanan yang diberikan.

Berdasarkan hasil analisis bivariat karakteristik jenis kelamin dengan tingkat kepercayaan pasien atas pelayanan yang diberikan oleh dokter residen diperoleh $\mathrm{p}$ value $0,104>0,05$ maka dapat disimpulkan tidak ada hubungan yang bermakna antara karakteristik jenis kelamin dengan tingkat kepercayaan pasien atas pelayanan yang diberikan oleh dokter residen. Berdasarkan hasil penelitian Prasetiyo menunjukan hasil $\mathrm{p}$ value $0,921>0,05$ yang dapat diartikan tidak ada hubungan antara jenis kelamin dengan kualitas pelayanan kesehatan. Sehingga berdasarkan hasil penelitian tersebut tidak terdapatnya hubungan jenis kelamin dengan kualitas pelayanan kesehatan akan berdampak pula pada tingkat kepercayaan pasien atas pelayanan yang diberikan.

Berdasarkan hasil penelitian yang telah diuji secara statistik yang bermakna diantara jenis kelamin dengan tingkat kepercayaan pasien atas pelayanan yang diberikan dimana sebagian besar responden yang berjenis kelamin perempuan menghasilkan jumlah tingkat kepercayaan tinggi. Maka dari itu sebagai pembentuk persepsi pasien dimana perbedaan jenis kelamin antara laki-laki dan perempuan tentunya jenis kelamin perempuan memiliki persepsi terhadap suatu keyakinan atas penggunaan pelayanan kesehatan yang 
berbeda dengan laki-laki. Hal ini disebabkan menurut pendapat Oroh, dkk (2014) karena kaum perempuan lebih melihat kualitas pelayanan yang secara keseluruhan sesuai dengan apa yang ingin diharapkannya serta jenis kelamin memiliki pengaruh pada pandangan terhadap jasa yang diberikan. Berdasrkan hasil analisis bivariat karakteristik pekerjaan pasien dengan tingkat kepercayaan pasien atas pelayanan yang diberikan oleh dokter residen diperoleh $p$ value $0,751>0,05$ maka dapat disimpulkan tidak ada hubungan yang bermakna antara karakteristik pekerjaan pasien dengan tingkat kepercayaan pasien atas pelayanan yang diberikan oleh dokter residen. Hasil ini sejalan dengan hasil penelitian Prasetiyo (2015) yang menunjukan nilai $\mathrm{p}$ value karakteristik pekerjaan 0,178>0,05 yang menandakan tidak ada hubungan pekerjaan dengan kualitas pelayanan kesehatan.

Dalam hasil penelitian ini didapatkan hasil statistik yang tidak terdapatnya hubungan antara pekerjaan dengan tingkat kepercayan pasien atas pelayanan kesehatan, hal ini disebabkan karena sifat homogenitas data penelitian yang dimana sebagian besar responden adalah bekerja di sektor swasta menghasilkan tingkat kepercayaan tinggi. Dimana pekerjaan menurut Wijaksana (1992) dalam Ruditya \& Chalidyanto (2015) adalah keadaan ekonomi suatu keluarga yang akan berpengaruh besar terhadap persepsi. Sehingga pekerjaan yang identik dengan menghasilkan pendapatan dimana berdasarkan pendapatan tersebut setiap orang dapat memilih kualitas pelayanan kesehatannya yang sesuai dengan kebutuhan. Penilaian kualitas pelayanan kesehatan menurut pendapat Nova (2010) menyatakan bahwa penilaian terhadap kualitas pelayanan kesehatan sangat penting, sebab dapat digunakan untuk menilai seberapa jauh pelayanan yang diberikan serta yang memenuhi harapan dan memuaskan pengguna jasa. Sejalan dengan pendapat Nova tersebut didukung pendapat dari Sari (2013) dimana sebagai salah satu indikator mutu pelayanan kesehatan, dapat menjadi suatu pertimbangan pasien dalam memilih suatu rumah sakit yang akan menangani masalah kesehatannya serta indikator pelayanan kesehatan yang dipilih pasien sebagai prioritas ukuran kualitas pelayanan kesehatan yang cenderung akan menjadi sumber utama terbentuknya tingkat kepuasan pasien sehingga akan mengarah kepada tingginya tingkat kepercayaan pasien.

\section{SIMPULAN}

Berdasarkan hasil dan diskusi dapat disimpulkan bahwa tingkat kepercayaan pasien sebesar $82,57 \%$ memiliki tingkat kepercayaan tinggi, sebesar 17,43\% memiliki kepercayaan sedang dan tidak ada responden yang memiliki tingkat kepercayaan kurang atas pelayanan yang diberikan oleh dokter residen. Ada hubungan antara karakteristik pendidikan pasien dengan tingkat kepercayaan pasien atas pelayanan yang diberikan oleh dokter residen.

\section{DAFTAR PUSTAKA}

Erviana,O. 2013. Pengaruh Kualitas Pelayanan dan Kepercayaan Terhadap Kepuasan Pasien Rawat Inap Di RSUD Dr. Soewondo Kendal. Jurusan Manajemen. 
Fakultas Ekonomi. Universitas Negeri Semarang.

Kartika ,dkk. 2014. Pengaruh Kualitas Layanan terhadap Kepuasan dan Kepercayaan di RS Bunda Kandangan Surabaya. Jurusan Manajemen. Fakultas Ekonomi dan Bisnis. Universitas Brawijaya.

Kurniasih,D. 2010. Beberapa Faktor yang Berhubungan dengan Tingkat Kepercayaan Pasien dalam Tindakan Medis di Semarang Eye Center (SEC). Rumah Sakit Islam Sultan Agung Semarang. Fakultas Kesehatan Masyarakat. Universitas Diponegoro.

Nova,R. 2010. Pengaruh Kualitas Pelayanan terhadap Kepuasan Pasien Rawat Inap Pada Rumah Sakit PKU Muhammadiyah Surakarta. Jurusan Manajemen. Fakultas Ekonomi. Universitas Sebelas Maret. Surakarta.

Oroh, dkk. 2014. Faktor-Faktor yang berhubungan dengan Tingkat Kepuasan Pasien Rawat Inap terhadap Pelayanan Keperawatan di Ruang Interna RSUD Noongan. Program Studi Ilmu Keperawatan. Fakultas Kedokteran. Universitas Sam Ratulangi. Manado.

Prasetiyo. 2015. Hubungan Kaarakteristik Pasien dengan persebsi pasien tentang kualitas pelayanan di Puskesmas Blora Kabupaten Blora. Fakltas Kesehatan Masyarakat. Universitas Dian Muswantoro. Jawa Tengah. Magister Ilmu Kesehatan Masyarakat. Fakultas Kesehatan Masyarakat. Universitas Sumatera Utara. Medan.

Respati.2015.Hubungan Mutu Pelayanan

Kesehatan dengan Tingkat Kepuasan Pasien Rawat Inap di Puskesmas
Halmahera Kota Semarang Tahun 2014. Jurusan Ilmu Kesehatan Masyarakat. Fak. Ilmu Keolahragaan. Univ. Negeri Semarang.

RSUP Sanglah Denpasar. 2016. Laporan Rencana Bisnis dan Anggaran Tahun 2016. Denpasar : RSUP Sanglah Denpasar.

Ruditya \& Chalidyanto. 2015. Hubungan Karakteristik Individu terhadap Penilaian Kualitas Produk Apotek Rawat Jalan. Fakultas Kesehatan Masyarakat. Universitas Airlangga. Surabaya.

Sari,P. 2013. Faktor-Faktor yang Mempengaruhi Keputusan Berobat Serta Dampaknya terhadap Kepuasan Pasien (Studi Kasus RS. Bhakti Wira Tamtama Semarang). Fakultas Ekonomika dan Bisnis. Universitas

Diponegoro.Semarang. 